\title{
The Influence of the Richness of Emotive-Cutural Lexicon in Coloring the Politeness Form of Speech and Politeness Gradation of the Coastal Javanese Society in Pati District
}

\author{
M. Suryadi ${ }^{1, *}$ and Riris Tiani $^{2}$ \\ ${ }^{1}$ Department of Indonesian literature, Faculty of Humanities, Diponegoro University, Semarang - Indonesia \\ ${ }^{2}$ Department of Indonesian literature, Faculty of Humanities, Diponegoro University, Semarang - Indonesia
}

\begin{abstract}
The focus of this research was to widen the richness of emotive-cultural lexicon which is grow rapidly in the usage area of coastal Javanese, especially in Pati District. By the variant of emotive-cultural lexicon will be found the uniqueness form of politeness and the gradation of politeness in the speaker walks of life. The location of this research was concentrate in Pati District. The selection of respondent and informant by using purposive sampling. The research design was survey and case study. The data collection was done by structured interview, indepth interview, and focus group discussion. The data was analyze using the connection of emotive-cultural lexicon toward the form of politeness speech, so that the direct substance sorting became the main device in the analysis. The research findings are the power of emotive-cultural lexicon becomes the spirit of speech politeness form for Javanese coastal society in the region of Pati. This spirit also developes the gradation of politeness for the speaker. Lingually, this gradation is determined by the color/variant of emotive-cultural lexicon than the power of extralingual.
\end{abstract}

Keywords: lexicon; emotive; cultural; politeness; coastal.

\section{Introduction}

Javanese has various uniqueness, either from the stratification of speech degree or the form of politeness speak. These two components is tehe representation of the order of Javanese culture that reflects the superiority of honor to other people, especially to keep the social harmony.

The Javanese society always give the priority of social harmony, revealed in the form of speech politeness which is created by the level of speech degree. The level of speech degree is realized by the form of polite behavior[1].

Through language, everyone can learn ethics, norms, and rules where they stand on. Language is a status gate for the speaker and the frame of their life.

Every Javanese society has their own uniqueness to incarnate the politeness form. Those uniqueness can not be detached from the influence of location/area and the understanding of politeness value itself. The truth of every language (dialect) either for the speaker can be maintained[2].

This research placed the language as the utterance (parole). The human/user factor as ACTOR, the activity of speech as ACTIVITY, purpose and role as TARGET, and the extralingual factor as sosio-cultural. This paradigm approximation is expected to answer the matter in attainment the form of politeness speak in coastal Javanese society.

The research that is oriented in coastal area of Paciran dialect, East Java, is more assert in the characteristic of pure possibility and pure necessity, especially related to the aspect of modality mesthi-mesthine, kudu-kudune, and paling. In this aspect showed that the sifnificant difference in the understanding value between the coastal area in East Java and Central Java[3].

Javanese in the Pati region as one of the coastal isolect that develop in the Northern coastal area of Central Java, has the richness of coastal cultural lexicon. The difference will be visible for each area of speech, which is showed by the entity of each isolect. The entity difference will raise the diversity that can not be detached from the cultural life[4].

\section{Research Method}

The location of the research is in Pati Regency. The decision is based on the consideration that the three regions has the high potention of lingual displacement phenomenon.

The data collection was done in the trianggulation way by some methods, there are: observation, structured interview, in-depth interview, and focus group discussion.

\footnotetext{
* Corresponding author: mssuryadi07@ gmail.com
} 
The chosen informants are Javanese speaker that comes from Javanese family, domicile in the research area, minimal for these five years. The Javanese family limitation in this research is the husband or wife that comes from Javanese ethnic and understand the culture of Javanese.

The kind of this second year research is descriptive qualitative with sociolinguistic approach. The method of analysis that is used is column method which completed with the column technique and row technique.

The determinant of column technique is the lingual unit. The device is the lingual unit that has the mental quality (language intuition). The determinant is lingual unit that has opened quality. By these opened quality itself, it can be possible emerge the new columns that the right direction of movement (signed by the arrow direction).

The row technique is consisted of the outside component of lingual unit, however the position and the role determine the the form of spoken lingual unit. The nonlingual unit are ACTOR, ACTIVITY, and TARGET. The ACTOR component is related to the participant of the speech event. The ACTIVITY is related to the verbal utterance which is influenced by the cultural aspect. The TARGET is realated to the speech behavior which is influenced by the participant attitude.

\section{The Politeness of Javanese Society}

The parameter of polite speak, basically is the way we speak to care the other participant's feeling. To care the feeling, all of the speakers must be, (1) pay attention to the hearer's self esteem by considered as the one who has the same status with the speaker (positive strategy) and (2) considered them in such a manner so that does not diminish the freedom in act of speech (negative strategy)[5].

Every Javanese society in where they live can not be detached from the social orders. Those social order is in the social institution environment and has the rule that the inhabitant society must be done obediently. The component of social order which is related to the lingual-behavior is the etiquette. The modesty is connected with the subasita, an appreciate behavior of other people (empan papan). The politeness is an expression of regard feeling toward the other people's feeling. The kind of politeness in a Javanese community can be mean as the symbol of honorific by the speech in realization, materialized by the using of honorific. Universally, the politeness is used as the eforts to avoid ourself from the friction, offensiveness, and collision.

\section{Forms of politeness in the community of Java Society}

Every speech community has their own politeness pattern which appropriate with the applied principals in society where they live, although the universal principal is always exist. The politeness principal in speech community of standard Javanese language (Solo-Jogja) will be differ with the principal of coastal Javanese speech community, although both of them has the same basic in politeness.

The kind of speech politeness in coastal Javanese in Pati Regency can not be detached with the coastal area context which exists in the culture and society. The cultural context of coastal society is a collective knowledge which is owned by the participants of the situation and condition along with the every built speech event. These context can not be detached with the coastal area culture.

The concept of politeness in Javanese is not an absolute thing, so that can not be measured by the same parameter. The degree of politeness is vary according to the cultural condition which is owned by the society, including Pati. Every society has their own degree (and different) to understand the degree of politeness owned by the society, incluing the society of Pati

The form of politeness speech in Pati, especially krama has the significant difference compare with the Javanese krama in Solo-Jogja. Those differences in form, often makes the $\mathrm{C}$ coastal Java language is labeled as the unappropriate Javanese or ora bisa basa. The error or more appropriately called the uniqueness -if it is viewed that every single language is good for their own speaker-, situated on the understanding toward the usage of krama vocabulary in speech.

The form of speech uniqueness in coastal Java language which is reflected the politeness cohering in the speech of krama inggil. The kind of krama inggil speech that developed in the usage area of Pati, mentioned below.

The form of speech uniqueness in coastal Java language which is reflected the politeness cohering in the speech of krama inggil. The kind of krama inggil speech that developed in the usage area of Pati, mentioned below.

1) ordinary manners: Kula nembe mucal 'I am teaching'

2) high manners: Kula tasih ngasta 'I am teaching'

3) ordinary manners: Adiem tuku duduh 'Your brother buys vegetables'

4) high manners: Adiem mundhut duduh 'Your brother buys vegetables'

5) ordinary manners: Kula nembe tilem 'I am sleeping'

6) high manners: Kula tasih sare 'I am sleeping'

The speech (1-6) developed in coastal areas, knowned as the speech of coastal Javanese language (language of manners). These forms has the uniquness, there are (a) labeled as the deviate Javanese speech from the rule of standard Javanese/ unacceptance form; (b) labeled as the unique form, the uniqueness is in the sag of krama inggil lexicon placement in speech. In the coastal Javanese language, krama inggil lexicon can be used for the speaker itself except for the hearer or addressee. Meanwhile, in standard Javanese it is considered as taboo if the vocabulary of krama inggil used for the speaker itself. 


\section{Conclusion}

The finding of this research is emotive-cultural lexicon has the power as the determinant spirit of politeness degree. The degree of politeness for every language usage area is differ based on the power of ACTOR, ACTIVITY, TARGET, and the sociocultural life of social institution in the language usage society. Lingually, these gradation is determined by the various emotive-cultural lexicon than the power of extralingual. This extra-lingual strength is one of the markers that eco-friendly coastal communities avoid carbon use.

\section{References}

1. M. Dwiraharjo. Fungsi Bentuk Krama dalam Masyarakat Tutur Jawa, Studi Kasus di Kotamadya Surakarta. (1997).

2. Suryadi, M. Sebagai Salah Satu Bentuk Kesantunan. Parole 5, 10-13 (2014).

3. Klok, J. Vander. Pure Possibility and Pure Necessity Modals in Paciran Javanese. Ocean. Linguist. 52, 341-374 (2013).

4. Sukarno. The Reflection of the Javanese Cultural Concepts in the Politeness of Javanese. No Title. $k @ t a$ Vol. 12, p59-71. 13p (2010).

5. Brown, P. \& Levinson, S. C. Universals in language usage: Politeness phenomena. Quest. PolitenessStrategies Soc. Interact. (1978). 